\title{
Effect of Planting Dates and Varieties on Potato Yield
}

\author{
S.N. Dash ${ }^{*}$, S. Behera and Y. Pushpavathi \\ Department of Horticulture, OUAT, Bhubaneswar-751003, India \\ *Corresponding author
}

\begin{tabular}{l} 
Ke y w o r d s \\
$\begin{array}{l}\text { Potato, Date of } \\
\text { planting, Variety, } \\
\text { Yield, Economics }\end{array}$ \\
Article Info \\
\hline $\begin{array}{l}\text { Accepted: } \\
\text { 16 February } 2018 \\
\text { Available Online: } \\
\text { 10 March } 2018\end{array}$ \\
\hline
\end{tabular}

Keywords

Potato, Date of planting, Variety,

Article Info

Accepted:

Available Online:

10 March 2018

\section{A B S T R A C T}

There is a huge gap in the demand and production of potato in the state of Odisha. One of the main causes of low potato productivity in the state is the short and mild winter during the growing period. Late showing and improper choice of varieties make the problem many folds. In the present experiment with five planting dates and four varieties, $15^{\text {th }}$ November emerged as the best planting date with a maximum tuber yield of $24.019 \mathrm{t}$ $\mathrm{ha}^{-1}$. Kufri Pukhraj was found to be the best variety with $24.426 \mathrm{t} \mathrm{ha}^{-1}$ tuber yield. This variety when planted on $25^{\text {th }}$ of October resulted in both highest net return of Rs. 80073/- ha ${ }^{-1}$ and B: C ratio of 2.23 . Late planting of $5^{\text {th }}$ December in Kufri Chandramukhi resulted in a negative net return of Rs. 2933/- ha $^{-1}$.

\section{Introduction}

Potato is the staple food of almost half of the world's population (Thiele et al., 2010). India is the second largest producer of potato in the world (Saxena and Mathur, 2013). In Odisha potato is very important among vegetables. The crop is grown in about 7000 hectares in the state with a total production of around 100 thousand tonnes. The low productivity in the state is attributed to several factors. The most important among them is the short, mild and fluctuating winter during which the crop is grown. In the coastal districts where the winter is very short, early varieties and in comparatively longer winter areas of inland districts medium duration varieties are under cultivation. Planting date is considered very important to take the full advantage of the short growing period. Since tuberization rate in potato declines above a temperature of $17^{\circ} \mathrm{C}$, increasing temperature may lead to reduced yields in potato varieties now cultivated close to the upper climatic limits of the crop that would not be recovered by higher levels of carbon dioxide. Earlier planting is not possible due to unfavourable weather conditions, particularly late rains. Early planted potatoes are high in starch content (White and Sanderson, 1983) and low in glucose and fructose (Nelson and Shaw, 1976) whereas, delayed planting results in reduced dry matter and starch content and increased reducing sugar (Lisinska and Leszczynski, 
1987) and nitrogen content (Wierzejska et al., 1973) of the tubers. Therefore, standardization of the optimum date of planting is not only important for yield but also to ensure better tuber quality. Moreover, varieties also differ in their ability to yield under different temperature regimes. In view of these facts the present investigation was designed to find out a suitable potato variety and the optimum date of planting to maximize productivity of the crop in Odisha.

\section{Materials and Methods}

The field experiment was conducted at the experimental plots of All India Coordinated Research Project on Potato, Orissa University of Agriculture and Technology, Bhubaneswar, located at $20^{\circ}$ North latitude, $86^{\circ}$ East longitude and at about $45 \mathrm{~m}$ above MSL consecutively for three years. The soil for the study was sandy loam in texture, acidic $(\mathrm{pH}$ $5.56)$ in reaction, low in organic carbon $(0.51$ $\%)$ and available $\mathrm{N}\left(218.4 \mathrm{~kg} \mathrm{ha}^{-1}\right)$, medium in both available $\mathrm{P}\left(20.8 \mathrm{~kg} \mathrm{ha}^{-1}\right)$ and $\mathrm{K}(96.1 \mathrm{~kg}$ $\left.\mathrm{ha}^{-1}\right)$. The treatments were a combination of five planting dates (D) and four varieties (V). The five dates of planting followed in the experiment were $25^{\text {th }}$ October, $5^{\text {th }}$ November, $15^{\text {th }}$ November, 25 $5^{\text {th }}$ November and $5^{\text {th }}$ December in all the years. The varieties were Kufri Chandramukhi and Kufri Ashoka in the early and Kufri Jyoti and Kufri Pukhraj in the medium duration groups. The seed tubers of these varieties were kept in cold store till planting. Well sprouted foundation seed tubers were planted in $4.2 \mathrm{~m}$ x $3.4 \mathrm{~m}$ sized plots at 60 $\mathrm{x} 20 \mathrm{~cm}$ spacing in a factorial randomized block design with four replications. Standard cultural practices were followed for raising a successful crop. A fertilizer dose of nitrogen (N)@120 kg/ha, phosphorous (P) @ $80 \mathrm{Kg}$ $\mathrm{P}_{2} \mathrm{O}_{5}$ / ha and potassium (K) @ $100 \mathrm{Kg} \mathrm{K} 2 \mathrm{O} / \mathrm{ha}$ were applied. Full $\mathrm{P}$ and $\mathrm{K}$ and half of $\mathrm{N}$ were applied at the time of planting and rest half $\mathrm{N}$ was top dressed at the time of earthing up. The growth and yield attributers were recorded on five randomly selected plants in each treatment and replication 50 days after planting (DAP). The crop was dehaulmed at 70 DAP in early and 90 DAP in medium duration varieties. Harvesting was done 10 days after haulm cutting. The harvested tubers from each plot with a net plot size of $3.6 \mathrm{~m} \mathrm{x}$ $3.6 \mathrm{~m}$ were graded into two sizes, viz. small $(<25 \mathrm{~g})$ and marketable $(>25 \mathrm{~g})$ grades. Economic parameters, viz. gross return and cost of cultivation were calculated based on the prevailing local market price of inputs and produce. Benefit: cost ratio (B: $\mathrm{C}$ ratio) was expressed as gross return per rupee spent. The data accumulated for three years were pooled and statistically analyzed following the procedure outlined by Gomez and Gomez (1984).

\section{Results and Discussion}

\section{Growth parameters}

The plant emergence recorded after 30 days of planting was significantly affected by the treatments (Table 1). Among different dates of planting, $15^{\text {th }}$ November had highest plant stand of $87.7 \%$ whereas, $25^{\text {th }}$ November planting resulted in lowest value of $84.7 \%$. Among the varieties, Kufri Chandramukhi germinated lowest $(82.1 \%)$ and K. Pukhraj the highest $(90.1 \%)$ over different planting dates. Plant height was observed to be significantly highest in K. Jyoti $(42.0 \mathrm{~cm})$ and lowest in K. Chandramukhi $(32.9 \mathrm{~cm})$. The difference in plant height of the varieties were possibly due to their difference in growing duration groups, K. Jyoti being the medium and K. Chandramukhi the short duration varieties. $\mathrm{D}_{2}$ planting date recorded the highest plant height $(37.5 \mathrm{~cm})$ but $\mathrm{D}_{3}, \mathrm{D}_{4}$ and $\mathrm{D}_{5}$ were at par. However, $\mathrm{D}_{5}\left(5^{\text {th }}\right.$ December planting) resulted in lowest plant height $(34.5 \mathrm{~cm})$ because the winter had already set in with low temperature hindering plant growth. 
Table.1 Emergence (\%) and growth characters of potato plant and tuber number as affected by planting dates (Data pooled over three years)

\begin{tabular}{|c|c|c|c|c|c|c|}
\hline \multirow[t]{2}{*}{ Treatment (D/V) } & \multicolumn{4}{|c|}{ Growth attributes } & \multicolumn{2}{|c|}{ Grade wise tuber number ha-1 } \\
\hline & Emergence $(\%)$ & Plant height $(\mathrm{cm})$ & Shoots plant ${ }^{-1}$ & Compound leaves plant ${ }^{-1}$ & Marketable tuber number $(>25 \mathrm{~g})$ & Total tuber number \\
\hline \multicolumn{7}{|l|}{ Date of planting } \\
\hline D1 & 85.9 & 35.0 & 3.8 & 48.5 & 316181 & 433264 \\
\hline$\overline{\text { D2 }}$ & 85.5 & 37.5 & 3.9 & 39.0 & 298751 & 428230 \\
\hline D3 & 87.7 & 37.3 & 4.2 & 50.2 & 367153 & 482535 \\
\hline D4 & 84.7 & 36.9 & 3.8 & 45.9 & 370479 & 493361 \\
\hline D5 & 87.1 & 34.5 & 3.5 & 42.2 & 313653 & 458206 \\
\hline C.D. (0.05) & 2.45 & 1.87 & 0.30 & 2.47 & 21047 & 22802 \\
\hline \multicolumn{7}{|l|}{ Variety } \\
\hline V1 & 82.1 & 32.9 & 3.5 & 30.8 & 282472 & 397615 \\
\hline $\mathbf{V 2}$ & 85.1 & 34.8 & 3.3 & 41.5 & 318466 & 449633 \\
\hline V3 & 87.5 & 42.0 & 4.5 & 57.4 & 367917 & 485472 \\
\hline V4 & 90.1 & 35.3 & 4.1 & 50.9 & 364117 & 503756 \\
\hline C.D. (0.05) & 2.18 & 1.67 & 0.27 & 2.21 & 18824 & 20394 \\
\hline
\end{tabular}

Table.2 Influence of date of planting on grade wise tuber yield and economics of potato production

\begin{tabular}{|c|c|c|c|c|c|c|c|}
\hline \multirow[t]{2}{*}{ Treatment (D/V) } & \multicolumn{2}{|l|}{ Yield of tubers $\left(\mathbf{t} \mathbf{h a}^{-1}\right)$} & \multirow{2}{*}{$\begin{array}{l}\text { Sale rate } \\
\left(\text { Rs.' } \mathbf{t}^{-1}\right)\end{array}$} & \multirow{2}{*}{$\begin{array}{l}\text { Gross Return } \\
\left(\text { Rs. ' ha }{ }^{-1}\right)\end{array}$} & \multirow{2}{*}{$\begin{array}{l}\text { Cost of Cultivation } \\
\text { (Rs.' } \mathbf{h a}^{-1} \text { ) }\end{array}$} & \multirow{2}{*}{$\begin{array}{l}\text { Net Return } \\
\left.\text { (Rs.' } \mathbf{h a}^{-1}\right)\end{array}$} & \multirow[t]{2}{*}{ B:C Ratio } \\
\hline & $\begin{array}{c}\text { Marketable tuber yield }(>25 \\
\text { g) }\left(\mathrm{t} \mathrm{ha}^{-1}\right)\end{array}$ & $\begin{array}{l}\text { Total tuber yield } \\
\qquad\left(\mathrm{t} \mathrm{ha}^{-1}\right)\end{array}$ & & & & & \\
\hline D1 & 18.665 & 20.110 & 5750 & 115633 & 64276 & 51072 & 1.80 \\
\hline D2 & 19.199 & 20.764 & 4875 & 101225 & 64276 & 36239 & 1.57 \\
\hline D3 & 22.648 & 24.019 & 4500 & 108086 & 64276 & 43637 & 1.68 \\
\hline D4 & 22.389 & 23.876 & 4000 & 95504 & 64276 & 31077 & 1.49 \\
\hline D5 & 18.671 & 19.635 & 3750 & 73631 & 64276 & 9946 & 1.15 \\
\hline C.D. (0.05) & 1.030 & 1.170 & - & - & - & - & - \\
\hline V1 & 16.235 & 17.634 & 4725 & 83321 & 63319 & 19466 & 1.32 \\
\hline $\mathbf{V 2}$ & 19.737 & 20.690 & 4600 & 95174 & 63319 & 31463 & 1.50 \\
\hline V3 & 22.590 & 23.973 & 4550 & 109077 & 65232 & 42322 & 1.67 \\
\hline V4 & 22.695 & 24.426 & 4425 & 108085 & 65232 & 43739 & 1.66 \\
\hline C.D. $(0.05)$ & 0.130 & 1.050 & - & - & - & - & - \\
\hline
\end{tabular}


Table.3 Influence of date of planting and variety on tuber number, yield and economics of potato

\begin{tabular}{|c|c|c|c|c|c|}
\hline \multirow{2}{*}{$\begin{array}{l}\text { Date of Planting } \\
\text { (D) }\end{array}$} & \multirow[t]{2}{*}{ Variety (V) } & \multicolumn{2}{|c|}{ Yield of tubers $(\mathrm{t} \mathrm{ha}-1)$} & \multirow{2}{*}{$\begin{array}{l}\text { Net Return } \\
\left(\text { Rs. }^{-} \mathrm{ha}^{-1}\right)\end{array}$} & \multirow{2}{*}{$\begin{array}{l}\text { B:C } \\
\text { Ratio }\end{array}$} \\
\hline & & Marketable (> $25 \mathrm{~g}$ ) & Total & & \\
\hline \multirow{4}{*}{$25^{\text {th }}$ October } & K. Chandramukhi & 14.526 & 16.763 & 35161 & 1.56 \\
\hline & K. Ashoka & 17.943 & 18.624 & 43769 & 1.69 \\
\hline & K. Jyoti & 18.256 & 19.220 & 45283 & 1.69 \\
\hline & K. Pukhraj & 23.936 & 25.832 & 80073 & 2.23 \\
\hline \multirow[t]{4}{*}{$5^{\text {th }}$ November } & K. Chandramukhi & 12.897 & 14.600 & 11506 & 1.18 \\
\hline & K. Ashoka & 19.590 & 20.651 & 39934 & 1.63 \\
\hline & K. Jyoti & 21.668 & 23.138 & 44672 & 1.68 \\
\hline & K. Pukhraj & 22.642 & 24.665 & 48845 & 1.75 \\
\hline \multirow[t]{4}{*}{$15^{\text {th }}$ November } & K. Chandramukhi & 19.128 & 20.389 & 30981 & 1.49 \\
\hline & K. Ashoka & 21.978 & 23.088 & 40575 & 1.64 \\
\hline & K. Jyoti & 25.357 & 26.729 & 55045 & 1.84 \\
\hline & K. Pukhraj & 24.127 & 25.869 & 47946 & 1.74 \\
\hline \multirow[t]{4}{*}{$25^{\text {th }}$ November } & K. Chandramukhi & 19.768 & 20.832 & 22614 & 1.36 \\
\hline & K. Ashoka & 21.193 & 22.434 & 26415 & 1.42 \\
\hline & K. Jyoti & 24.915 & 26.628 & 41280 & 1.63 \\
\hline & K. Pukhraj & 23.679 & 25.608 & 33999 & 1.52 \\
\hline \multirow[t]{4}{*}{$5^{\text {th }}$ December } & K. Chandramukhi & 14.854 & 15.584 & $(-) 2933$ & 0.95 \\
\hline & K. Ashoka & 17.983 & 18.651 & 6622 & 1.10 \\
\hline & K. Jyoti & 22.752 & 24.149 & 25328 & 1.39 \\
\hline & K. Pukhraj & 19.093 & 20.156 & 7833 & 1.12 \\
\hline C.D. $(0.05)(\mathrm{D})$ & & 1.030 & 1.170 & - & - \\
\hline C.D. $(0.05)(V)$ & & 0.130 & 1.050 & - & - \\
\hline $\begin{array}{l}\text { C.D. (0.05) (DXV) } \\
\text { C. (DX) }\end{array}$ & & 2.050 & 2.340 & - & - \\
\hline
\end{tabular}

Number of shoots per plant was significantly maximum (4.2) in $\mathrm{D}_{3}$ and minimum (3.5) in $\mathrm{D}_{5}$. K. Jyoti recorded a maximum of 4.5 shoots per plant and $\mathrm{K}$. Ashoka the minimum of 3.3 .

The number of leaves per plant was highest (50.2) under $\mathrm{D}_{3}$ and a distinctly lowest (42.2) under $\mathrm{D}_{5}$. Similarly, K. Pukhraj had significantly the highest (57.4) number of leaves per plant and $\mathrm{K}$. Chandramukhi the lowest (30.8). The low growth characters noticed in $\mathrm{D}_{5}$ was mainly attributed to the low temperature after planting whereas the same were observed under early varieties like $\mathrm{K}$. Ashoka and K. Chandramukhi.

\section{Yield characters}

The number and yield under both marketable tubers (> $25 \mathrm{~g}$ ) and total tubers categories were affected significantly with the dates of planting and varieties (Table 1 and 2). Among the five dates of planting $25^{\text {th }}$ November planting $\left(\mathrm{D}_{4}\right)$ had highest tuber number in both categories which were at par with the $15^{\text {th }}$ November planting $\left(\mathrm{D}_{3}\right)$. Among the varieties, K. Jyoti resulted in highest number of both marketable and total tubers which were at par with those in K. Pukhraj variety. Such a response that tuber size distribution is affected by the genotype is confirmed by the results of Sharma et al., (2013). Tuber yields 
obtained in both marketable and total tuber categories were maximum (22.648 and 24.019 $\mathrm{t} \mathrm{ha}^{-1}$, respectively) in $15^{\text {th }}$ November planting which were at par with those of $25^{\text {th }}$ November planting (Table 2). Low tuber yield of $19.635 \mathrm{t} \mathrm{ha}^{-1}$ was obtained under the late planting of $5^{\text {th }}$ December as the crops were harvested towards high temperature and long day conditions. Van Dam et al., (1996) have also stated that high temperature and long days favour assimilate partitioning to the above ground vegetative parts, as a result, above ground bio-mass and plant height increased and tuber yield is reduced. Kushwah and Govindakrishnan (2003) have indicated that the optimum temperature for good crop growth and development ranges between $15-25^{\circ} \mathrm{C}$. Among the varieties though K. Pukhraj recorded highest tuber yield under marketable and total tubers (22.695 and $24.426 \mathrm{t} \mathrm{ha}^{-1}$, respectively) they were at par with those from K. Jyoti. The interaction between dates of planting and varieties clearly demonstrate that $\mathrm{K}$. Jyoti under $15^{\text {th }}$ November planting achieved highest yield of total tubers $\left(26.729 \mathrm{t} \mathrm{ha}^{-1}\right)$ (Table 3). The other varieties K. Chandramukhi yielded maximum $(20.832 \mathrm{t}$ $\mathrm{ha}^{-1}$ ) of total tubers under $25^{\text {th }}$ November and both K. Ashoka (23.088 t ha ${ }^{-1}$ ) and K. Pukhraj (25.869 $\left.\mathrm{t} \mathrm{ha}^{-1}\right)$ under $15^{\text {th }}$ November planting, respectively.

\section{Economics}

A critical analysis of the economics potato production has been presented in Table 2 and 3 . The first date of planting, i.e. $25^{\text {th }}$ October showed a maximum net return of Rs. 51072 $\mathrm{ha}^{-1}$ and a highest B: C ratio of 1.80 which was mainly attributed to early high market sale price (Rs. $5750 \mathrm{t}^{-1}$ ). Among the varieties a maximum net return of Rs. $43739 \mathrm{ha}^{-1}$ was achieved by K. Pukhraj and a highest B: C ratio of 1.67 by $\mathrm{K}$. Jyoti. The interaction effect of planting date and varieties indicated a maximum net return of Rs. $80073 \mathrm{ha}^{-1}$ and highest B: C ratio of 2.23 from K. Pukhraj under the earliest planting date, i.e. $25^{\text {th }}$ of October. It is also pertinent to note that extended planting to the latest date, i.e. $5^{\text {th }}$ December resulted in a negative net return of Rs. 2933 in the event of low tuber yield $\left(15.584 \mathrm{t} \mathrm{ha}^{-1}\right)$ and low sale rate due to market glut.

\section{Acknowledgement}

The authors sincerely acknowledge the financial assistance received from ICAR in conducting the research work.

\section{References}

Gomez, K.A. and Gomez, A.A. 1984. Statistical Procedures for Agricultural Research. John Wiley and Sons, New York, USA: 684p.

Kushwah, V.S. and Govindakrishnan P.M. 2003. Cultural practices for seed and ware potato. In: The Potato Production and Utilization in Sub-tropics. (Eds.) S.M. Paul Khurana et al., Mehta Publishers, New Delhi. Pp.104-110.

Lisinska and Leszczynski. 1987. $9^{\text {th }}$ KartoffelTagung, Detmold, Germany, pp. 3-4.

Nelson, D.C. and Shaw, R. 1976. Effect of planting and harvest dates, location in the hill and tuber size on sugar content of Kennebec potatoes. Am. Potato J., 53 (1): $15-21$

Saxena, R. and Mathur, P. 2013. Analysis of potato production performance and yield variability in India. Potato J. 40 (1): 38-44.

Sharma, A.K., E.P. Venkatasala and Kumar, V. 2013. Potato mini-tuber production during main and off crop seasons in high hills of north-western Himalaya. Potato J. 40(1): 29-37.

Thiele, G., K. Theisen, M. Bonierbale and Walker, T. 2010. Targeting the poor and 
hungry with potato science. Potato J. 37: 75-86.

Van Dam, J., P.L. Kooman and Struik, P.C. 1996. Effect of temperature and photoperiod on early growth and final number of tubers in potato. Potato Res. 39: 52-62.
White, R.P. and Sanderson J.B. 1983. Effect of planting date, nitrogen rate, and plant spacing on potatoes grown for processing in Prince Edward Island. Am. Potato J., 60 (2): 115-26.

Wierzejska, A., M. Fotyma and Fotyma, E. 1973. Biul. Inst. Ziemn., Poland, 12: 6380.

\section{How to cite this article:}

Dash, S.N., S. Behera and Pushpavathi, Y. 2018. Effect of Planting Dates and Varieties on Potato Yield. Int.J.Curr.Microbiol.App.Sci. 7(03): 1868-1873.

doi: https://doi.org/10.20546/ijcmas.2018.703.221 